NOTICE: This is the author's version of a work that was accepted for publication in Hydrometallurgy. Changes resulting from the publishing process, such as peer review, editing, corrections, structural formatting, and other quality control mechanisms may not be reflected in this document. Changes may have been made to this work since it was submitted for publication. A definitive version was subsequently published in Hydrometallurgy [108, 1-2, 2011] DOI 10.1016/j.hydromet.2011.03.002 


\section{Accepted Manuscript}

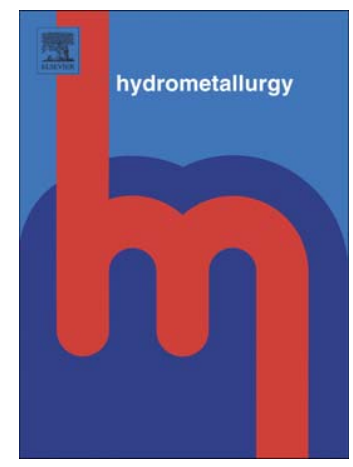

The recovery of nucleic acid from biomining and acid mine drainage microorganisms

Carla M. Zammit, Lesley A. Mutch, Helen R. Watling, Elizabeth L.J. Watkin

PII: $\quad$ S0304-386X(11)00065-X

DOI: $\quad$ doi: 10.1016/j.hydromet.2011.03.002

Reference: $\quad$ HYDROM 3358

To appear in: $\quad$ Hydrometallurgy

Received date: $\quad 11$ February 2010

Revised date: $\quad 22$ February 2011

Accepted date: $\quad 4$ March 2011

Please cite this article as: Zammit, Carla M., Mutch, Lesley A., Watling, Helen R., Watkin, Elizabeth L.J., The recovery of nucleic acid from biomining and acid mine drainage microorganisms, Hydrometallurgy (2011), doi: 10.1016/j.hydromet.2011.03.002

This is a PDF file of an unedited manuscript that has been accepted for publication. As a service to our customers we are providing this early version of the manuscript. The manuscript will undergo copyediting, typesetting, and review of the resulting proof before it is published in its final form. Please note that during the production process errors may be discovered which could affect the content, and all legal disclaimers that apply to the journal pertain. 


\title{
The recovery of nucleic acid from biomining and acid mine drainage
}

\section{microorganisms}

\author{
Carla M. Zammit ${ }^{\mathrm{a}}$, Lesley A. Mutch ${ }^{\mathrm{a}}$, Helen R. Watling ${ }^{\mathrm{b}}$ and Elizabeth L.J. Watkin ${ }^{\mathrm{a}^{*}}$ \\ ${ }^{a}$ Parker Cooperative Research Centre for Integrated Hydrometallurgy Solutions, Curtin University of Technology, \\ School of Biomedical Sciences, GPO Box U1987, Perth, Western Australia, 6845 \\ ${ }^{b}$ Parker Cooperative Research Centre for Integrated Hydrometallurgy Solutions, CSIRO Minerals, PO Box 7229 , \\ Karawara, Western Australia, 6152. \\ *Corresponding author: Tel +61 89266 2955, Fax +61 89266 2342. E-mail: E.Watkin@ curtin.edu.au.
}

\begin{abstract}
The cornerstone of biological molecular techniques is the extraction of the intra- or extra- cellular component of interest. However, inefficiencies in the extraction method can lead to results that are not representative of the microbial population under investigation. It is particularly difficult to extract clean and pure samples of the cellular component of interest from the microbial inhabitants of low-pH, sulfidic environments, such as those found in biomining or acid mine drainage (AMD). A number of nucleic acid (NA) extraction methods were tested using microorganisms commonly found in biomining and AMD environments, including archaea and Gram-negative and Grampositive bacteria. The different stages in the methods of NA extraction were investigated separately, including the: (i) removal of cells from pyrite, (ii) cell lysis and nucleic acid extraction, (iii) nucleic acid precipitation and (iv) RNA purification using, as appropriate, microscopy, spectrophotometry, agarose gel electrophoresis of NA, PCR, quantitative-PCR and quantitative reverse transcriptasePCR to asses the quality and quantity of the DNA and RNA. The relative percentage of NA recovered from each microorganism using the optimised method discussed in this paper returned the following percentage of NA per cell: At. ferrooxidans $91 \% \pm 1.4 \%$; At. caldus $91 \% \pm 2.7 \%$; L.
\end{abstract}


ferriphilum $98 \% \pm 1.2 \% ;$ F. acidiphilum $83 \% \pm 2.9 \%$; and S. thermosulfidooxidans $79 \% \pm 0.7 \%$.

Differences in lysis methods and NA precipitation greatly impacted the quality and quantity of the extracted NA. A method for the reliable, representative and reproducible extraction of NA from five strains of biomining and AMD microorganisms from pyrite and from liquid culture is described.

Keywords: Acid mine drainage; Bioleaching, Biomining; Microorganisms; DNA extraction; RNA extraction.

\section{Introduction}

The foundation of all biological molecular techniques is the representative, reproducible and reliable extraction of the cellular material of interest. In this age of high-throughput molecular techniques, the efficiencies of basic methodologies, such as nucleic acid (NA) extraction, are often forgotten or disregarded. However, any biases inherent in the selected NA extraction technique will have a direct impact on the data obtained from downstream analyses and, hence, on the overall understanding of the environment under investigation.

To identify the microorganisms within an environment samples must first be collected, then the NA extracted, amplified and analysed. To amplify a segment of NA polymerase chain reaction (PCR) based technologies are commonly used. The cornerstone of the PCR is an enzyme, Taq polymerase, originally isolated from a microorganism that grows near hot springs and hydrothermal vents. The activity of this enzyme is greatly influenced by exogenous factors, such as the presence of chemicals and inhibitors, which impacts the results obtained by downstream analysis.

The importance of accurate and reliable extraction of NA when quantifying environmental microorganisms is well-recognised by soil microbiologists (Miller et al., 1999; Lloyd-Jones and Hunter, 2001; Hurt et al., 2001; Stach et al., 2001; Braid et al., 2003; de Lipthay et al., 2004; 
Feinstein et al., 2009). Downstream applications can be greatly influenced by the presence of inhibitors such as humic acids and mineral particles. In addition, the diverse range of microorganisms that populate soils makes the representative extraction of NA essential. Biomining or acid mine drainage (AMD) environments exhibit some similar physical characteristics to soils, yet few papers have been found in which the available methods of NA extraction are evaluated for application to acidic, sulfidic samples (Zeng et al., 2008).

The comparatively high levels of minerals, low $\mathrm{pH}$, diversity of microorganisms and the attachment of microorganisms to mineral surfaces all affect NA extraction from biomining and AMD samples:

- Mineral particles and elements, such as iron and copper, can inhibit PCR. This is of particular significance in quantitative PCR (q-PCR), where exogenous standards are used to determine the quantity of DNA in the starting material (Zammit et al., 2008).

- Low pH can affect the activity of enzymes used in subsequent methods (such as in PCR and restriction enzyme digests) and the stability of DNA.

- The diversity of microorganisms includes eukaryotes, archaea, Gram-negative and Grampositive bacteria, each of which can have different cell wall composition, which are varyingly susceptible to lysis. The thorough treatment that is required for the lysis of Grampositive bacteria may result in the shearing of Gram-negative NA.

- Biomining microorganisms often form biofilms on the surface of sulfide minerals. It is essential to account for both the attached and unattached microorganisms when quantifying and describing the microbial population of an environment.

There are a number of different methods currently employed for NA extraction from biomining and AMD microorganisms but the applicability of these techniques are rarely evaluated. If they are evaluated, then the effectiveness of NA extraction is generally assessed by the quality and quantity of the NA. However, as many of these studies are focused upon the identities and numbers of 
microorganisms within the community, the representative extraction of NA from the microbial strains present is of the utmost importance. For example; a biomining environment may contain two bacteria, one a Gram-negative and one Gram-positive. These bacteria are present in equal proportions, but during cellular lysis only lysozyme was used, meaning that only the Gram-positive bacteria was sufficiently lysed. When this sample is studied in downstream applications only the Gram-positive microorganisms is identified, or, if the quantities of the bacteria were studied it would appear that the Gram-positive microorganisms dominated and was the source of the leaching.

The aim of this study was to develop an effective method for the representative extraction of NA from five known biomining and AMD microorganisms; Acidithiobacillus caldus, Acidithiobacillus ferrooxidans and Leptospirillum ferriphilum (all Gram-negative bacteria), Sulfobacillus thermosulfidooxidans (a Gram-positive bacteria) and Ferroplasma acidiphilum (an archaea). Selected methods for the extraction of NA were separated into their constituent parts, such as (i) the removal of cells from pyrite, (ii) cell lysis and nucleic acid extraction, (iii) nucleic acid precipitation, and (iv) RNA purification. Each part was tested using a number of commonly used techniques. The method developed included detergent to remove the cells from pyrite, enzymatic lysis of cells, precipitation of NA with polyethylene glycol and the purification of RNA with DNase (an enzyme which breaks down DNA). The suitability of this method was demonstrated for downstream applications such as PCR, reverse transcriptase-PCR (a method of converting RNA to its complementary form of DNA and then amplifying this DNA) and q-PCR.

\section{Materials and methods}

\subsection{Type strains and growth conditions}


All strains were grown in medium containing $0.4 \mathrm{gL}^{-1}\left(\mathrm{NH}_{4}\right)_{2} \mathrm{SO}_{4}, 0.4 \mathrm{gL}^{-1} \mathrm{MgSO}_{4} .7 \mathrm{H}_{2} \mathrm{O}, 0.4$ $\mathrm{gL}^{-1} \mathrm{KH}_{2} \mathrm{PO}_{4}$ and $1 \mathrm{~mL} \mathrm{~L}^{-1}$ of filter-sterilised trace salts solution. The trace salts solution contained $62 \mathrm{mgL}^{-1} \mathrm{MnCl}_{2} \cdot \mathrm{H}_{2} \mathrm{O}, 68 \mathrm{mgL}^{-1} \mathrm{ZnSO}_{4} \cdot 7 \mathrm{H}_{2} \mathrm{O}, 64 \mathrm{mgL}^{-1} \mathrm{CoCl}_{2} \cdot 6 \mathrm{H}_{2} \mathrm{O}, 30 \mathrm{mgL}^{-1} \mathrm{H}_{3} \mathrm{BO}_{3}, 10 \mathrm{mgL}^{-1}$ $\mathrm{Na}_{2} \mathrm{MoO}_{4}, 66 \mathrm{mgL}^{-1} \mathrm{CuCl}_{2} .2 \mathrm{H}_{2} \mathrm{O}, 30 \mathrm{mgL}^{-1} \mathrm{NaVO}_{3}$, made with distilled water and the $\mathrm{pH}$ was adjusted to 1.8 with $\mathrm{H}_{2} \mathrm{SO}_{4}$. Sterilised $\mathrm{FeSO}_{4} \cdot 7 \mathrm{H}_{2} \mathrm{O}$, elemental sulphur $\left(\mathrm{S}^{\circ}\right)$ and/ or yeast extract (YE) was added to the medium, as indicated below (Zammit et al. 2008).

Comparative tests were conducted using the following species: Acidithiobacillus ferrooxidans $\operatorname{DSM} 14482^{\mathrm{T}}\left(20 \mathrm{gL}^{-1} \mathrm{FeSO}_{4} .7 \mathrm{H}_{2} \mathrm{O}\right)$ and Leptospirillum ferriphilum $\mathrm{DSM} 14647^{\mathrm{T}}\left(20 \mathrm{gL}^{-1}\right.$ $\left.\mathrm{FeSO}_{4} .7 \mathrm{H}_{2} \mathrm{O}\right)$, Ferroplasma acidiphilum DSM12658 ${ }^{\mathrm{T}}\left(13.901 \mathrm{gL}^{-1} \mathrm{FeSO}_{4} .7 \mathrm{H}_{2} \mathrm{O}, 0.16 \mathrm{gL}^{-1} \mathrm{YE}\right)$, Sulfobacillus thermosulfidooxidans DSM9293 ${ }^{\mathrm{T}}\left(13.901 \mathrm{gL}^{-1} \mathrm{FeSO}_{4} .7 \mathrm{H}_{2} \mathrm{O}, 0.2 \mathrm{gL}^{-1} \mathrm{YE}\right)$ or Acidithiobacillus caldus DSM8584 ${ }^{\mathrm{T}}\left(5 \mathrm{gL}^{-1} \mathrm{~S}^{\circ}\right)$.

Finely ground pyrite $(5 \% \mathrm{w} / \mathrm{v})$ was sterilised by adding it to in $100 \mathrm{~mL}$ of medium then placing it in an autoclave held at $121^{\circ} \mathrm{C}$ for $45 \mathrm{~min}$, this was repeated three separate times. The type strains were adapted to growth on pyrite by successive incremental replacement of $\mathrm{Fe}^{2+}$ or $\mathrm{S}^{\circ}$ by $25 \%$ with pyrite. Strains were cultured weekly until growth was maintained solely on pyrite. Three replicates of each treatment were used to test the methods described below.

\subsection{Cell counts}

Cells were diluted to 10 cells per $0.0025 \mathrm{~mm}^{2}$ (or $4 \times 10^{4}$ cells per $\mathrm{mL}$ ) in phosphate buffered saline (pH 1.8) and counted using a Helber bacteria counting chamber (Hawksley) and $400 \times$ magnification phase contrast microscopy. Cellular lysis was assessed by microscopic inspection of samples prior and post lysis treatments and live cell were quantified by counting motile cells. 


\subsection{Removal of cells from pyrite}

An aliquot $(15 \mathrm{~mL})$ of the culture containing pyrite particles and microorganisms was centrifuged at $3,000 \times g$ for $\sim 5 \mathrm{~min}$ and then the liquid phase separated from the particulate phase using a pipette. The amount of pyrite was weighed out for each experiment, so that $0.5 \mathrm{~g}$ was used for direct comparison. For the liquid phase cells were counted and $5 \times 10^{8}$ cells were used for each method. The liquid phase was processed directly using the NA extraction methods (next section). The following methods for removing microorganisms from the mineral surface were applied to the particulate phase.

The FastDNA ${ }^{\circledR}$ Spin Kit for Soil (MP Biomedicals, LLC), Soil Master ${ }^{\mathrm{TM}}$ DNA Extraction Kit (Epicentre $^{\circledR}$ ) and UltraClean ${ }^{\mathrm{TM}}$ Soil DNA Kit (Mo Bio) were tested following the manufacturers instructions. Pyrite $(0.5 \mathrm{~g})$ was mixed by vortex for $10 \mathrm{~s}$ in $1.5 \mathrm{~mL} 1 \%$ Tween 20 (Sigma Aldrich $^{\circledR}$ ).

The mixture was incubated at $68^{\circ} \mathrm{C}$ on a rotary shaker at $90 \mathrm{rpm}$ for $5 \mathrm{~min}$ and then centrifuged for $30 \mathrm{~s}$ at $3,000 \times g$. The supernatant was retained and the pyrite was re-incubated in $1.5 \mathrm{~mL} 1 \%$ Tween 20 and again centrifuged. The supernatants were pooled, centrifuged at $20,000 \times g$ for 30 min to pellet the cells and NA was extracted using the enzymatic lysis method (next section).

\subsection{NA extraction}

\subsubsection{Cell recovery.}

In those cases where an iron(III) hydroxy precipitate or insoluble sulfur was visible in the culture, the sample was briefly centrifuged $(<5 \mathrm{~min})$ at $3,000 \times g$ and the supernatant was retained. Cells were pooled from this supernatant by centrifugation at $20,000 \times g$ for $10,20,30,40$ and $60 \mathrm{~min}$. The optimal centrifugation time was determined by cell counts of the supernatant at each time interval. Following centrifugation, cells were re-suspended in $1 \mathrm{~mL}$ phosphate buffered saline (pH 1.8). For cells that were to be used for RNA analysis the liquid phase was filtered through a $0.2 \mu \mathrm{m}$ 
membrane (Pall Corp., Supor) and washed off the filter with buffer A (buffer A; $5.84 \mathrm{gL}^{-1} \mathrm{NaCl}$, $12.11 \mathrm{gL}^{-1}$ Tris, $0.29 \mathrm{gL}^{-1} \mathrm{Na}$ citrate, $0.38 \mathrm{gL}^{-1} \mathrm{CaCl}_{2}, 9.31 \mathrm{gL}^{-1}$ EDTA, $\mathrm{pH}$ 8.0, stored at $4{ }^{\circ} \mathrm{C}$ ).

\subsubsection{Enzymatic lysis.}

This method was adapted from Bond et al. (2000). Unless otherwise stated all mixtures were treated with diethylpyrocarbonate (DEPC; $1 \mathrm{~mL} \mathrm{~L}^{-1}$ of solution) and left to stand overnight at $22{ }^{\circ} \mathrm{C}$ then autoclaved. Cells were centrifuged at $20,000 \times g$ for 20 min and resuspended in $500 \mu \mathrm{L} 2 \times$ buffer A. Cells were either treated with lysozyme (for the indicated times below), proteinase (for the indicated times below) or lysozyme followed by proteinase (for $20 \mathrm{~min}$ each, which was shown to be the optimal treatment time). In order, polyadenylic acid potassium salt ( $20 \mu \mathrm{L}$ of $10 \mathrm{mg} \mathrm{mL}^{-1}$, Sigma Aldrich ${ }^{\circledR}$, prepared with RNase, DNase free, double distilled water $\left(\mathrm{ddH}_{2} \mathrm{O}\right)$, stored at -20 ${ }^{\circ} \mathrm{C}$ ), $20 \mu \mathrm{L}$ of $10 \%$ pyrophosphate (Sigma Aldrich ${ }^{\circledR}, \mathrm{ddH}_{2} \mathrm{O}$, and filter sterilised, stored at room temperature) and $30 \mu \mathrm{L}$ of $100 \mathrm{mg} \mathrm{mL}^{-1}$ lysozyme $\left(\right.$ Amresco ${ }^{\circledR}$, freshly prepared with $\mathrm{ddH}_{2} \mathrm{O}$ ) were added to the cells and incubated at $37^{\circ} \mathrm{C}$ for $10,20,30,40$ or 60 min. Treatment with proteinase $\mathrm{K}$ involved the addition of $10 \mu \mathrm{L} 20 \%$ sodium decyl sulfate and $60 \mu \mathrm{L}$ proteinase $\mathrm{K}$ (Amresco ${ }^{\circledR}$, freshly prepared with $\mathrm{ddH}_{2} \mathrm{O}$ ) and incubated at $50{ }^{\circ} \mathrm{C}$ for $10,20,30,40$ or $60 \mathrm{~min}$. Cell numbers were rechecked microscopically. Phenol-chloroform-isoamyl alcohol reagent (Sigma Aldrich ${ }^{\circledR}$, $500 \mu \mathrm{L}, 24: 24: 1 \mathrm{v} / \mathrm{v} / \mathrm{v}$, stored at $4{ }^{\circ} \mathrm{C}$ ) was added and gently mixed by vortex. This was centrifuged at $15,000 \times g$ at $4{ }^{\circ} \mathrm{C}$ for $5 \mathrm{~min}$ and the supernatant was transferred into a fresh tube $(600 \mu \mathrm{L})$. An equal volume of phenol-chloroform-isoamyl alcohol reagent was added and mixed by inversion, centrifuged at $15,000 \times g$ for 5 min, then the supernatant was transferred into a fresh tube $(500 \mu \mathrm{L})$. NA was precipitated using both polyethylene glycol (PEG) and isopropanol methods (next section).

\subsubsection{Mechanical lysis.}

Cells were centrifuged at $20,000 \times g$ for 20 min and re-suspended in $500 \mu \mathrm{L} 2 \times$ buffer $\mathrm{A}$ and 500 $\mu \mathrm{L}$ phenol-chloroform-iso-amyl alcohol reagent. This mixture was added to approximately $0.3 \mathrm{~g}$ 
glass beads (212-300 $\mu \mathrm{m}$, Sigma Aldrich ${ }^{\circledR}$, sterilised by dry heat baking at $120{ }^{\circ} \mathrm{C}$ for $\left.2 \mathrm{hrs}\right)$. The bead mixture was shaken three times for $45 \mathrm{~s}$ in the FastPrep ${ }^{\circledR}$ FP120 shaker at speed 6.0. The presence of live cells was checked microscopically by counting motile cells. This bead mixture was centrifuged at $15,000 \times g$ for $5 \mathrm{~min}$ at $4{ }^{\circ} \mathrm{C}$. The supernatant $(600 \mu \mathrm{L})$ was transferred into a fresh tube and an equal volume $(600 \mu \mathrm{L})$ of phenol-chloroform-isoamyl alcohol reagent was added, mixed by inversion and then the mixture centrifuged at $15,000 \times g$ for $5 \mathrm{~min}$. The supernatant (500 $\mu \mathrm{L}$ ) was transferred into a fresh tube and NA was precipitated with PEG for $2 \mathrm{~h}$ (next section).

\subsubsection{Mechanical lysis followed by enzymatic lysis.}

Cells were centrifuged at $20,000 \times g$ for 20 min and resuspended in $750 \mu \mathrm{L} 2 \times$ buffer A, $0.3 \mathrm{~g}$ glass beads were added, and the mixture shaken for three 45 -second periods on the FastPrep shaker at speed 6.0. The glass beads were discarded by brief centrifugation at 3,000 $\times g$, the supernatant removed and cells were checked microscopically to determine the number of motile live cells. Enzymatic lysis with lysozyme and proteinase $\mathrm{K}$ for 20 min each and PEG NA precipitation for $2 \mathrm{~h}$ then followed.

\subsection{NA precipitation}

\subsubsection{Polyethylene glycol (PEG).}

To a volume of extracted NA $(500 \mu \mathrm{L})$, two volumes of DEPC-treated 30\% PEG 8000/1.6M $\mathrm{NaCl}$ (stored at room temperature) were added and incubated at $-20{ }^{\circ} \mathrm{C}$ for 2 and $16 \mathrm{~h}$ (two treatments). Samples were centrifuged at $15,000 \times g$ at $4{ }^{\circ} \mathrm{C}$ for $20 \mathrm{~min}$, the pellets rinsed with 500 $\mu \mathrm{L}$ cold $70 \%$ ethanol (made with DEPC-treated water, at $-20^{\circ} \mathrm{C}$ ) and centrifuged at $15,000 \times g$ at 4 ${ }^{\circ} \mathrm{C}$ for $5 \mathrm{~min}$. Tubes were inverted and left to air dry (30 min) and then resuspended in $30 \mu \mathrm{L}$ $\mathrm{ddH}_{2} \mathrm{O}$.

\subsubsection{Iso-propanol.}


To a volume of extracted NA $(500 \mu \mathrm{L})$, two volumes of $100 \%$ isopropylaclcohol was added followed by the addition of sodium acetate to give a final concentration of $0.3 \mathrm{M}$. This was incubated for 2 or $16 \mathrm{~h}$ (two treatments) at $-20^{\circ} \mathrm{C}$, centrifuged at $15,000 \times g$ at $4{ }^{\circ} \mathrm{C}$ for $20 \mathrm{~min}$. The pellet was then rinsed with $500 \mu \mathrm{L}$ of $70 \%$ ethanol at $-20{ }^{\circ} \mathrm{C}$, centrifuged, tubes were inverted

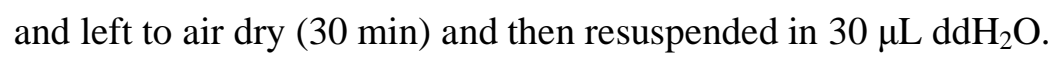

\subsection{RNA purification}

\subsubsection{DNase.}

To $8 \mu \mathrm{L}$ NA preparation (adjusted with $\mathrm{ddH}_{2} \mathrm{O}$ to contain $600 \mu \mathrm{g}$ of NA), $1 \mu \mathrm{L}$ RQ1 RNase free DNase $\left(\right.$ Promega $^{\mathrm{TM}}$ ) and $1 \mu \mathrm{L}$ of $10 \times$ reaction buffer $\left(\right.$ Promega $^{\mathrm{TM}}$ ) was added. This was incubated for 30,60 and $120 \mathrm{~min}$ at $37{ }^{\circ} \mathrm{C}$. The reaction was (a) stopped with $1 \mu \mathrm{L}$ RQ1 DNase stop solution and incubation at $65^{\circ} \mathrm{C}$ for $10 \mathrm{~min}$, or (b) stopped by the addition of $1 \mu \mathrm{L}$ of $0.5 \mathrm{M}$ EDTA (pH 7.5).

\subsubsection{Qiagen, Inc. RNeasy Kit.}

The manufacturers' instructions from step 7 were followed, which was the beginning of the RNA clean-up step.

\subsubsection{Qiagen, Inc. RNeasy Kit followed by RNase treatment.}

Manufacturers' instructions from step 7 were followed. The resulting solution was then treated with DNase, as above, for 30 min and the reaction was stopped with EDTA.

\subsubsection{Qiagen, Inc. QuantiTech ${ }^{\circledR}$.}

Manufacturers' instructions were followed until step 3, which was at the end of the clean-up steps, before the reverse transcription.

\subsection{Determining the quality of the extraction}


The purity and quantity of extracted NA was determined spectrophotometrically using the NanoDrop 1000 spectrometer (Thermo Fisher Scientific, Inc.). Additionally, agarose gel (1\%) was also used to check the quality of NA. Agarose gel (1\%) was prepared with TBE (89 mM Tris, 89 $\mathrm{mM}$ boric acid, 2 mM EDTA, pH 8.2) electrophoresis followed by ethidium bromide staining was used to visualise NA with the molecular weight ladders Hyperladder II and IV (Bioline, Inc.). A PCR was conducted using universal 16S primers [27F and 1492R (Lane, 1991)] to check that the DNase was efficiently removing all of the DNA. For quantitative-PCR (q-PCR) the method described in (Zammit et al., 2008) was followed. For quantitative reverse transcriptase PCR (qRTPCR), cDNA was constructed using the Qiagen, Inc. QuantiTech ${ }^{\circledR}$ kit following the manufactures instructions, with the exception of the addition of a control that contained extracted NA, treated to remove DNA but not transcribed to cDNA for each reaction. This ensured that all genomic DNA had been removed and the method was detecting RNA only. All reactions were performed in triplicate with a negative control, which contained only the reagents and no NA, and a positive control, which contained DNA known to amplify with the selected primers.

\section{Results and discussion}

The aim of this study was to investigate several methods that have been used to extract NA from soils, biomining and AMD environments and evaluate their effectiveness for producing NA of good quantity, quality and that is representative of all the microbial species present.

\subsection{Removal of cells from pyrite}

The most efficient removal of cells from pyrite was achieved by the Tween 20 method, as assessed by the greatest amount of NA recovered of the best quality. The quantity and purity of 
DNA can be measured by spectrophotometry where the absorbance at $260 \mathrm{~nm}$ divided by the absorbance at $280 \mathrm{~nm}\left(\mathrm{~A}_{260} / \mathrm{A}_{280}\right)$ indicates the ratio of DNA and RNA; a ratio of 1.8 is pure DNA, and a ratio of 2.0 is pure RNA, the $\mathrm{A}_{230} / \mathrm{A}_{280}$ gives the purity of NA; pure DNA has a ratio of 1.82.2, co-extraction of contaminants will alter this ratio. To determine the quantity of NA the $\mathrm{A}_{260}$ is used. Using the Tween 20 method an $\mathrm{A}_{260} / \mathrm{A}_{280}$ of 1.8 and $\mathrm{A}_{230} / \mathrm{A}_{280}$ of 1.7 was achieved. The FastDNA $^{\circledR}$ Spin Kit for Soil was the most effective of the three kits tested, but returned significantly less NA $(\mathrm{P}<0.05)$ compared with the Tween 20 method and, on inspection by agarose gel electrophoresis, the DNA exhibited a greater degree of shearing. In soil science, the repeated removal of cells from the soil has been shown to be critical to the success of the procedure (Feinstein et al., 2009). The Tween 20 method required three extraction cycles compared with only one for the other methods examined, which could have contributed to the greater success of this method. For the analysis of RNA a major disadvantage of the Tween 20 method is the time taken to remove cells from the starting material, in this case pyrite. Additionally, the removal of cells from the surfaces of different minerals may require individual optimisation for each mineral type and the evaluation of whether cells tightly bound to minerals surfaces are being removed or just loosely bound cells is also an issue which will need to be addressed in the future.

\subsection{Cell recovery}

S. thermosulfidooxidans, At. ferrooxidans, At. caldus and F. acidiphilum all had greater than $82 \%$ recovery of cells by centrifugation after $10 \mathrm{~min}$; at $20 \mathrm{~min}$ the recovery was greater than $97 \%$ and at 30 min full recovery (100\%) was achieved. For L. ferriphilum recoveries of only 55\% at 10 min, $86 \%$ at $20 \mathrm{~min}$ and $95 \%$ at $30 \mathrm{~min}$ were achieved. A centrifugation time of 20 min was selected and used for the centrifugation of all cells, unless otherwise stated. For RNA extraction, cells were recovered using a $0.2 \mu \mathrm{m}$ filter, allowing the cells to be collected as quickly as possible (within $10 \mathrm{~min}$ ). This method would also be suitable for DNA extraction. 


\subsection{Lysis}

Cell lysis can be achieved by mechanical or chemical methods, the latter using either detergents and/or enzymes. Generally, a combination of these methods is required to achieve complete cellular lysis. In this study it was found that enzymatic lysis methods routinely out-performed mechanical lysis methods (Table 1), consistent with the results of Lloyd-Jones and Hunter (2001). The amounts of NA extracted from the replicates varied by an average of $1.29 \%$, with the greatest variation between replicated being $3.86 \%$ and lowest $0.04 \%$, indicating that the results are reproducible. Mechanical methods lysed only a very small proportion of the cells, Gram-negative bacteria $A t$. ferrooxidans and At. caldus being the most amenable to mechanical lysis. Mechanical lysis followed by enzymatic lysis was more effective than mechanical lysis alone, but less effective than enzymatic lysis alone. Of the enzymatic lysis methods tested, proteinase $\mathrm{K}$ was more effective than lysozyme, with greater than $95 \%$ of cells lysed in $20 \mathrm{~min}$ for the Gram-negative bacteria At. ferrooxidans, At. caldus, L. ferriphilum and the archaeon F. acidiphilum. Cells of the Gram-positive S. thermosulfidooxidans were the most difficult to lyse, as expected, because the cell-wall composition of Gram-positive bacteria are less amenable to lysis (Salazar and Asenjo 2007 and references therein). Lysozyme was the most efficient method of lysing S. thermosulfidooxidans, with $70 \%$ of cells lysed after 20 min, compared to $49 \%$ lysis after treatment with proteinase $\mathrm{K}$ for the same time period. A combination of lysozyme for $20 \mathrm{~min}$ then proteinase $\mathrm{K}$ for another $20 \mathrm{~min}$ proved to be the most effective, but increasing the incubation time to greater than 20 min had little effect.

A bias in the efficiency of lysis across microorganisms with various cell wall compositions was a major concern of this study. Although a completely unbiased method of cellular lysis was not achieved, it was possible to minimise the differences across cell types. The described method gives 
a reasonable representation of the microbial population under investigation, and future research may reduce the difference in extraction efficiencies, particularly between Gram-negative and Grampositive bacteria.

\subsection{NA precipitation}

From previous work it was shown that NA precipitation methods significantly influenced the quantity and quality of NA extracted from biomining microorganisms (Zammit et al., 2008). LloydJones and Hunter (2001) reported that "purification losses are surprisingly high with both precipitation-based and proprietary DNA purification methods". Two precipitation-based methods were tested using different incubation times. For all the test species and the two incubation times, precipitation with PEG was superior to precipitation with iso-propanol (Table 2). This result is consistent with, but more pronounced than, the difference reported by Lloyd-Jones and Hunter, (2001). In addition, the duration of incubation was also shown to affect the quality of the NA significantly. A two-hour incubation was chosen because it produced a higher quality (but less quantity) of recovered NA, compared with a 16-hour incubation.

The quality of the extracted NA can be seen in the $A_{260} / A_{280}$ ratio, agarose gel electrophoresis and the results of downstream applications. The mean NA recovered by a $2 \mathrm{~h}$ incubation time with PEG was $82 \%$ (in comparison to the total NA recovered after treatment with PEG for $24 \mathrm{~h}$ ) with $\mathrm{A}_{260} / \mathrm{A}_{280}$ of 1.8 to 2.0 and an $\mathrm{A}_{230} / \mathrm{A}_{280}$ of 2.0. An increased concentration of EDTA was added to the agarose gel to suppress the activity of any RNase or DNase that could degrade the NA as it migrated through the gel. On a 1\% agarose gel, the intact genomic DNA, 23S rRNA, 16S rRNA, 5S rRNA and tRNA can be seen (Figure 1). Degradation products are also viable on the gel; however in comparison to the pre-optimised method the NA is more intact (Figure 1). The presence of the 5S band on the gel shows that the RNA has not been subject to much degradation and that even a 
length of $\sim 158 \mathrm{bp}$ can be investigated in downstream applications. The $16 \mathrm{~S}$ rRNA band commonly exhibited the same intensity as the $23 \mathrm{~S}$ rRNA band. Due to rRNA stoichiometry this is expected and hence suggests that the RNA had not been degraded to any great extent. The 5S rRNA band was only slightly less intense than the $23 \mathrm{~S}$ rRNA and 16S rRNA bands, again suggesting minimal degradation had occurred.

In summary, the most effective method of NA extraction involved the following steps: (i) removal of cells from pyrite using Tween 20 , (ii) harvesting of cells by centrifugation at $20,000 \times g$ for 20 min or by filtration using a $0.2 \mu \mathrm{m}$ pore-size membrane, (iii) lysis with lysozyme and proteinase $\mathrm{K}$ both with 20 min incubation periods, and (iv) precipitation of NA with PEG with a two-hour incubation. Strain variation was seen in the efficiency of the extraction but was greatly reduced by the optimisation of the method (Table 2). The DNA obtained using the described method is of high quality and was suitable for downstream applications such as PCR, q-PCR, qRT-PCR, restriction enzyme digests, terminal restriction fragment length polymorphisms, DNA sequencing and cloning (unpublished data). As the NA extracted was of high molecular weight it would also be suitable to use in large fragment cloning.

The mean weight of NA returned for each microorganism was as follows: At. ferrooxidans $1490 \mathrm{ng}$; At. caldus 1466 ng; L. ferriphilum 1198 ng; F. acidiphilum 822 ng; and S. thermosulfidooxidans $1672 \mathrm{ng}$. Differences in the efficiencies of returning NA from each cell using the optimised NA extraction method was determined by calculating the expected weight of the NA based on genome size. Once adjusted for the expected weight, the relative percentage recovery for each microorganism is as follows: At. ferrooxidans $91 \% \pm 1.4 \%$; At. caldus $90.8 \% \pm 2.7 \%$; L. ferriphilum $98 \% \pm 1.2 \% ; F$. acidiphilum $83 \% \pm 2.9 \%$; and $S$. thermosulfidooxidans $79 \% \pm 0.7 \%$. These numerical comparisons show the amount of NA extracted per a cell, differences in genome 
size and transcription levels would also affect the amount of NA extracted but were not included in calculations and could therefore be source of some variation observed across species.

\subsection{RNA purification}

The most successful treatments tested for the removal of genomic DNA were DNase (when the reaction was stopped with EDTA) and the Qiagen, Inc. QuantiTech ${ }^{\circledR}$ kit. Both of these methods produced RNA for PCR and qRT-PCR which did not contain detectable contamination with genomic DNA with any of the strains tested (Table 3). There was little variation in the results obtained for different species, the exception being the S. thermosulfidooxidans sample which, when treated with DNase, exhibited a genomic DNA-derived product visible after PCR and agarose gel electrophoresis. However, the NA load was at the upper-recommended limit described by the manufacturers, and lowering the amount of NA resolved this problem. The Qiagen, Inc.

QuantiTech ${ }^{\circledR}$ kit was chosen as the best method as it required less optimisation than the DNase treatment and was less labour intensive and time consuming. The RNA obtained with this purification method is of high quality and suitable for downstream applications such as qRT-PCR.

\section{Conclusions}

Efficiencies of NA extraction were compared for several methods and for five microorganisms known to be active in AMD and biomining systems. Based on the results, a method has been described for the representative and reproducible extraction of good quality and quantity of DNA and RNA from biomining microorganisms. Further refinement could reduce the remaining biases in the extraction method. Standardisation of NA extraction methods across the field should ensure that results from downstream applications are comparable. 


\section{Acknowledgements}

The support of the CSIRO Minerals Down Under Flagship and the Parker CRC for Integrated Hydrometallurgy Solutions is gratefully acknowledged. CZ would like to thank the Australian Government for the Australian Postgraduate Award, Curtin University of Technology and the Minerals and Energy Research Institute of Western Australia for their financial support of this research.

\section{References}

Bond, P.L., Smriga, S.P. and Banfield, J.F., 2000. Phylogeny of microorganisms populating a thick, subaerial, predominantly lithotrophic biofilm at an extreme acid mine drainage site. Appl. Environ. Microbiol., 66(9): 3842-3849.

Braid, M.D., Daniels, L.M. and Kitts, C.L., 2003. Removal of PCR inhibitors from soil DNA by chemical flocculation. J. Microbiol. Meth., 52(3): 389-393.

de Lipthay, J.R., Enzinger, C., Johnsen, K., Aamand, J. and Sorensen, S.r.J., 2004. Impact of DNA extraction method on bacterial community composition measured by denaturing gradient gel electrophoresis. Soil Biol. Biochem., 36(10): 1607-1614.

Feinstein, L.M., Sul, W.J. and Blackwood, C.B., 2009. Assessment of bias associated with incomplete extraction of microbial DNA from soil. Appl. Environ. Microbiol., 75(16): $5428-5433$.

Hurt, R.A. et al., 2001. Simultaneous recovery of RNA and DNA from soils and sediments. Appl. Environ. Microbiol., 67(10): 4495-4503.

Lane, D., 1991. 16S/23S rRNA Sequencing. Nucleic Acid Techniques in Bacterial Systematics. John Wiley \& Sons Ltd., Sussex.

Lloyd-Jones, G. and Hunter, D.W.F., 2001. Comparison of rapid DNA extraction methods applied to contrasting New Zealand soils. Soil Biol. Biochem., 33: 2053-2059.

Miller, D.N., Bryant, J.E., Madsen, E.L. and Ghiorse, W.C., 1999. Evaluation and optimisation of DNA extraction and purification procedures for soil and sediment samples. Appl. Environ. Microbiol., 65(11): 4715-4724.

Salazar, O., Asenjo, J.A., 2007. Enzymatic lysis of microbial cells. Biotechnol. Lett. 29: 985-994

Stach, J.E.M., Bathe, S., Clapp, J.P. and Burns, R.G., 2001. PCR-SSCP comparison of 16S rDNA sequence diversity in soil DNA obtained using different isolation and purification methods. FEMS Microbiol. Ecol., 36(2-3): 139-151.

Zammit, C.M., Mutch, L.A., Watling, H.R. and Watkin, E.L.J., 2008. Evaluation of quantitative real-time polymerase chain reaction for enumeration of biomining microorganisms in culture. Hydrometallurgy, 94(1-4): 185-189.

Zeng, L. et al., 2008. An effective method of DNA extraction for bioleaching bacteria from acid mine drainage. Appl. Microbiol. Biotech., 79: 881-888. 
Table 1. Effectiveness of cellular lysis of biomining and acid mine drainage microorganisms using enzymatic and mechanical methods.

\begin{tabular}{|c|c|c|c|c|c|}
\hline \multirow[b]{2}{*}{ Microorganism } & \multicolumn{3}{|c|}{ Enzymatic } & \multirow[b]{2}{*}{ Mechanical } & \multirow{2}{*}{$\begin{array}{l}\text { Mechanical } \\
\text { \& Enzymatic }\end{array}$} \\
\hline & Lysozyme & Proteinase $\mathrm{K}$ & $\begin{array}{l}\text { Lysozyme \& } \\
\text { Proteinase K }\end{array}$ & & \\
\hline Acidithiobacillus ferrooxidans & - & +++ & +++ & + & + \\
\hline Acidithiobacillus caldus & - & +++ & +++ & + & + \\
\hline Ferroplasma acidiphilum & - & +++ & +++ & - & + \\
\hline Leptospirillum ferriphilum & - & +++ & +++ & - & + \\
\hline Sulfobacillus thermosulfidooxidans & $+/++$ & $+/++$ & $++/+++$ & - & + \\
\hline
\end{tabular}

+++ complete lysis, ++ partial lysis, + some lysis, - no lysis.

Cells were grown then concentrated and subject to various treatments. Enzymatic treatments involved using lysozyme, proteinase $\mathrm{K}$ or lysozyme and proteinase $\mathrm{K}$ to lyse cells. For the mechanical method glass beads were used to try and lyses cells. Mechanical and enzymatic involved using glass beads followed by lysozyme and proteinase $\mathrm{K}$ to lyse cells. The amount of cellular lysis was determined by microscopy of pre and post treated cells. 
Table 2. Percentage of nucleic acid precipitated using various methods.

\begin{tabular}{|c|c|c|c|c|c|}
\hline \multirow{2}{*}{ Microorganism } & & \multicolumn{2}{|c|}{ Polyethylene Glycol } & \multicolumn{2}{|l|}{ Isopropanol } \\
\hline & & $2 \mathrm{hr}$ & $16 \mathrm{hr}$ & & $16 \mathrm{hr}$ \\
\hline \multirow{3}{*}{ Acidithiobacillus ferrooxidans } & $\%$ recovery & $95 \% \pm 0.6 \%$ & $100 \% \pm 0.2 \%$ & $4 \% \pm 0.2 \%$ & $7 \% \pm 3.3 \%$ \\
\hline & $\mathrm{A}_{260} / \mathrm{A}_{280}$ & 1.8 & 1.8 & $1.6 \pm 0.1$ & 1.4 \\
\hline & $\mathrm{A}_{260} / \mathrm{A}_{230}$ & 2.0 & $2.1 \pm 0.1$ & 1.6 & $1.1 \pm 0.1$ \\
\hline \multirow{3}{*}{ Acidithiobacillus caldus } & $\%$ recovery & $83 \% \pm 3.0 \%$ & $100 \% \pm 7.9 \%$ & $5 \% \pm 0.2 \%$ & $6 \% \pm 0.4 \%$ \\
\hline & $\mathrm{A}_{260} / \mathrm{A}_{280}$ & 2.0 & 1.5 & $2.0 \pm 0.1$ & 1.9 \\
\hline & $\mathrm{A}_{260} / \mathrm{A}_{230}$ & 2.0 & 1.1 & 2.0 & $2.2 \pm 0.1$ \\
\hline \multirow{3}{*}{ Ferroplasma acidiphilum } & $\%$ recovery & $72 \% \pm 0.5 \%$ & $100 \% \pm 0.8 \%$ & $18 \% \pm 0.3 \%$ & $94 \% \pm 13.0 \%$ \\
\hline & $\mathrm{A}_{260} / \mathrm{A}_{280}$ & 1.8 & 1.8 & $1.6 \pm 0.1$ & 1.3 \\
\hline & $\mathrm{A}_{260} / \mathrm{A}_{230}$ & 2.0 & 2.1 & $1.8 \pm 0.1$ & 1.2 \\
\hline \multirow{3}{*}{ Leptospirillum ferriphilum } & $\%$ recovery & $87 \% \pm 0.1 \%$ & $100 \% \pm 0.4 \%$ & $60 \% \pm 5.6 \%$ & $96 \% \pm 4.0 \%$ \\
\hline & $\mathrm{A}_{260} / \mathrm{A}_{280}$ & 1.8 & 1.6 & $1.4 \pm 0.1$ & $1.7 \pm 0.1$ \\
\hline & $\mathrm{A}_{260} / \mathrm{A}_{230}$ & 2.0 & 1.4 & 1.4 & $1.8 \pm 0.1$ \\
\hline \multirow{3}{*}{ Sulfobacillus thermosulfidooxidans } & $\%$ recovery & $71 \% \pm 1.0 \%$ & $100 \% \pm 2.5 \%$ & $51 \% \pm 12.3 \%$ & $94 \% \pm 0.4 \%$ \\
\hline & $\mathrm{A}_{260} / \mathrm{A}_{280}$ & 1.9 & 1.7 & $1.7 \pm 0.1$ & $1.3 \pm 0.1$ \\
\hline & $\mathrm{A}_{260} / \mathrm{A}_{230}$ & 2.0 & 2.1 & $1.9 \pm 0.1$ & $1.4 \pm 0.1$ \\
\hline \multicolumn{2}{|l|}{ Average $\%$ recovery } & $82 \%$ & $100 \%$ & $28 \%$ & $59 \%$ \\
\hline \multicolumn{2}{|l|}{$\mathrm{A}_{260} / \mathrm{A}_{280}$ range } & $1.8-2.0$ & $1.5-1.8$ & $1.4-2.0$ & $1.3-1.9$ \\
\hline \multicolumn{2}{|l|}{$\mathrm{A}_{260} / \mathrm{A}_{230}$ range } & 2.0 & $1.1-2.1$ & $1.4-2.0$ & $1.1-2.2$ \\
\hline
\end{tabular}

Values expressed are a relative percentage of the greatest quantity of NA recovered from each method. 
Table 3. Examination of methods for the removal of genomic DNA from NA extracted from biomining and acid mine drainage microorganisms

\begin{tabular}{|c|c|c|c|c|}
\hline Microorganism & DNase & $\begin{array}{l}\text { Qiagen, } \\
\text { Inc. } \\
\text { RNeasy Kit }\end{array}$ & $\begin{array}{l}\text { Qiagen, Inc. } \\
\text { RNeasy Kit \& } \\
\text { DNase }\end{array}$ & $\begin{array}{l}\text { Qiagen, Inc. } \\
\text { QuantiTech }^{\circledR}\end{array}$ \\
\hline Acidithiobacillus ferrooxidans & + & -- & -- & \\
\hline Leptospirillum ferriphilum & + & -- & -- & \\
\hline Ferroplasma acidiphilum & + & -- & -- & \\
\hline Sulfobacillus thermosulfidooxidans & - & --- & -- & + \\
\hline Acidithiobacillus caldus & + & -- & -- & + \\
\hline
\end{tabular}

+ suitable DNA removal procedure.

--- genomic DNA visible by agarose gel electrophoresis and ethidum bromide staining,

-- DNA derived product amplified by PCR and visible by agarose gel electrophoresis and ethidum bromide staining,

- DNA derived product detected by qRT-PCR. 


\section{FIGURE CAPTIONS}

Figure 1. Nucleic acid and RNA on an agarose gel, stained with ethidium bromide. 1\% Agarose gel, Lane 1: Bioline HyperLadder I, Lane 2: Extracted NA, Lane 3. Purified RNA. NA was extracted using the optimized method of lysing cells with lysozyme and proteinase K and precipitation of NA with PEG. Genomic DNA was removed from the sample in Lane 3 with the Qiagen, Inc.

QuantiTech $^{\circledR}$ kit. 


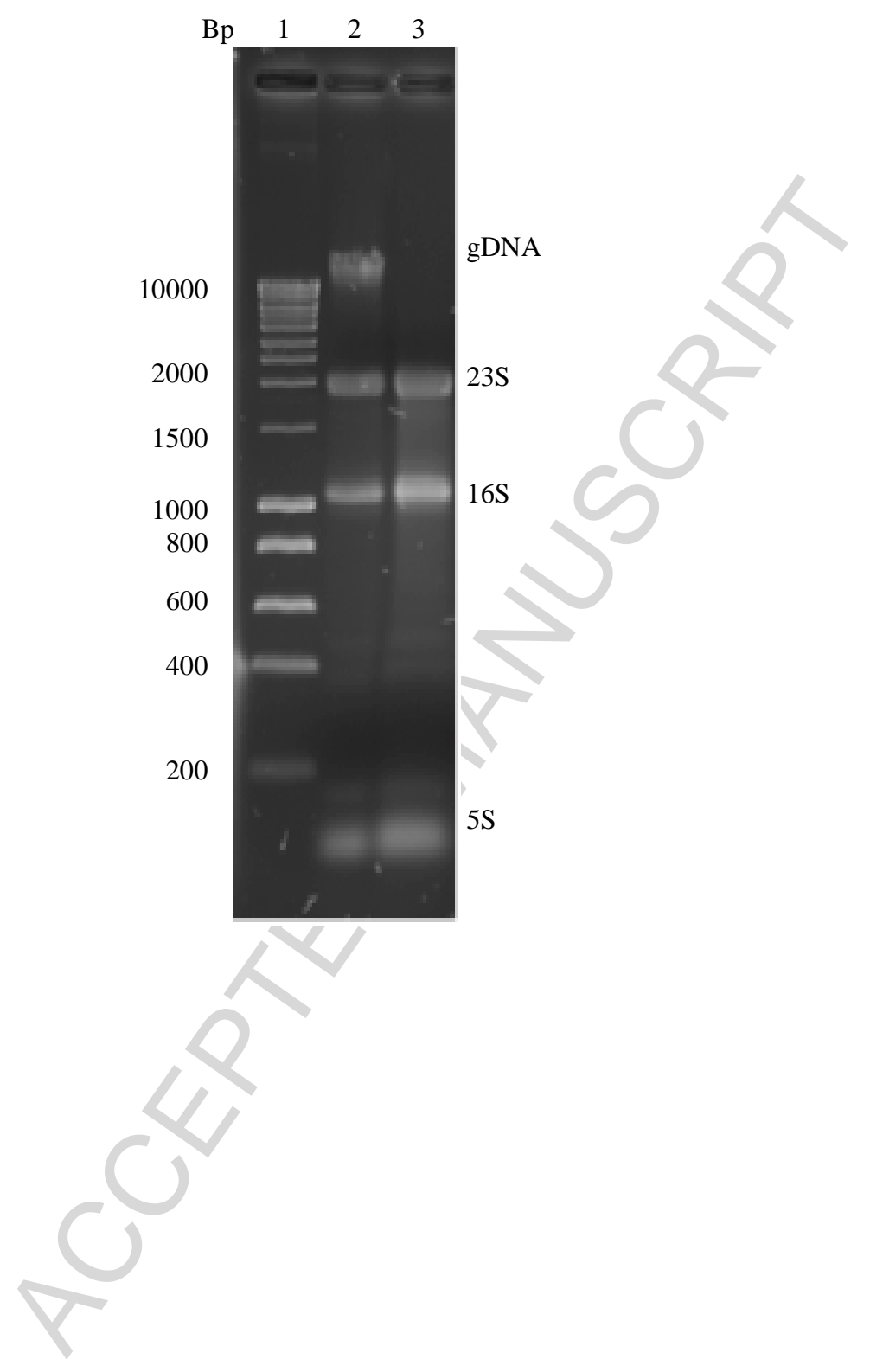

Figure 1. 


\section{Research Highlights}

A number of nucleic acid (NA) extraction methods were tested using microorganisms commonly found in biomining and AMD environments, including archaea and Gram-negative and Grampositive bacteria. The different stages in the methods of NA extraction were investigated separately, As a result, a method for the reliable, representative and reproducible extraction of NA from five strains of biomining and AMD microorganisms from pyrite and from liquid culture is described. 